\title{
Association of Oral Microbiota Properties on Hyaluronidase and Biofilm Formation
}

\author{
Nur Syarafina Mohd Zahir ${ }^{1}$, Nabila Huda Abdul Halim ${ }^{1}$ and Hanani Ahmad Yusof ${ }^{1^{*}}$ \\ ${ }^{1}$ Department of Biomedical Science, Kulliyyah of Allied Health Sciences, International \\ Islamic University Malaysia, Kuantan, Pahang, Malaysia
}

\begin{abstract}
Correlation between hyaluronidase ( $\mathrm{Hyl}$ ) activity and biofilm detachment in a few bacterial species was found. However, it is unclear if this association applies to bacterial species or for more general bacterial characteristics. This study determined the association between biofilm production and Hyl activity among bacterial isolates from the oral cavity of healthy subjects, and its association with Gram staining group, colony surface morphology and bacteria shape. The swab was taken from the tongue, cheek and entire teeth surfaces of 35 subjects, and tested for biofilm through modified microtiter plate assay while Hyl production was screened through HA rapid plate method. Fortyfour isolates were found, each 50\% are Gram-positive, and Gram-negative bacteria, with the majority are cocci and non-mucoid colony. More than $70 \%$ of isolates are moderate and strong; $(n=17,38.6 \%)$ and $(n=15,34.1 \%)$ respectively for biofilm production; and $68.2 \%$ are Hyl producer. A significant association was found between Hyl and bacterial shape $(p=0.018)$ and colony morphology $(p=0.018)$, while other association is not significantly measured, including between Hyl and biofilm ( $p=0.659)$. This study showed that biofilm production is not affected by the characteristics of the bacteria to produce or not produce hyaluronidase. Meanwhile, Hyl production is prone in rod shape and mucoid isolates which need further investigations.
\end{abstract}

Keywords: biofilm; hyaluronidase; colony morphology; Gram-positive; Gram-negative; bacterial shape

\section{INTRODUCTION}

Bacterial hyaluronidase (Hyl) is a virulence factor that involves in pathogenesis of disease in certain bacteria, where the most established studied bacteria are Staphylococcus aureus and Streptococcus pneumoniae (Ibberson et al. 2014). This enzyme degrades hyaluronic acid (HA) which abundantly present in the human body including the skin, umbilical cord, synovial fluid, eyes, lungs and skeletal tissues (Meyer \& Palmer 1934; Juhlin 1997; Armstrong \& Bell 2002; Papakonstantinou et al. 2008). In the oral cavity, HA was found in all periodontal tissues, particularly in gingiva and periodontal ligament (Dahiya \& Kamal 2013). It plays various roles as cell adhesion, migration and differentiation. Degradation of HA by Hyl enzyme reduces the viscosity of the tissue while increases the tissue permeability, where it can create a pathway for substance delivery and dispersion across the membrane (Necas et al. 2008). Previously, Pecharki et al. (2008) found the involvement of $\mathrm{Hyl}$ in biofilm detachment in Streptococcus intermedius isolated from the oral cavity. The findings were supported by Ibberson et al. (2016) who was found an increase of biofilm mass in the mutant Staphylococcus aureus strain lacking Hyl, which later was found to involve in biofilm detachment. At the moment, it is unclear if the association of Hyl inactivity is specific for different bacterial species, or to more general characteristics. It is because, most of the previous studies were conducted for specific bacterial species including Staphylococcus aureus, Streptococcus agalactiae, Streptococcus pneumoniae, Treponema pallidum and Clostridium perfringens (Fitzgerald \& Gannon 1983; Hynes \& Walton 2000; Hart et al. 2009). Thus this study was conducted to reveal if Hyl 
activity and biofilm production are influenced by any specific bacterial characteristics, based on its Gram's classification, bacterial shape and colony morphology.

\section{MATERIALS AND METHOD}

\section{A. Sample Collection}

This study was obtained ethical approval from IIUM Research Ethics Committee (IREC) (IREC 2017-042). The swab samples were taken from the tongue, cheek and entire teeth surfaces of 37 healthy subjects. The swabs were immediately streaked on nutrient and MacConkey agar (MAC) (Oxoid, Hampshire) and incubated aerobically at $37^{\circ} \mathrm{C}$ for 24 hours. The colony morphology was recorded where each different colony was stained with Gram's reagent for microscopic observation.

\section{B. Determination of Biofilm-Producing Isolates}

Detection of biofilm production was performed following microtiter plate method by Christensen et al. (1985) modified by Stepanovic et al. (2000). The isolates were grown in trypticase soy broth (TSB) medium supplemented with $1 \%$ glucose and incubated for 18 hours for sufficient bacteria growth. Then $200 \mu$ l of the cultures were inoculated further in individual 96 well plates. The well plates were incubated for 24 hours at $37^{\circ} \mathrm{C}$ in static condition. The content of wells plates was aspirated and washed three times with $200 \mu$ of sterile physiological saline before fixing with $200 \mu$ l of $99 \%$ methanol for 15 minutes. The plate was emptied and left to dry. Next, the wells were stained with $200 \mu$ l of crystal violet used for Gram staining for 5 minutes. The excess stain was removed by placing under running tap water. The content of the wells was resolubilized with $160 \mu$ l of $33 \%$ glacial acetic acid for 30 minutes. Micro enzyme-linked immunosorbent assay (ELISA) auto reader with wavelength $570 n$ m was used to measure the optical density (OD). The values are considered as the index of attachment to a surface. The classification of bacteria adherent category was done based on a formula introduced by Stepavonic et al. (2000).

\section{Screening of Hyaluronidase Production}

Each positive biofilm-producing bacteria isolates was screened for hyaluronidase production through rapid plate screening method (Smith \& Willet 1968). A single colony of isolates was streaked on brain heart infusion agar (Oxoid, Hampshire) plates containing $2 \mathrm{mg} / \mathrm{ml}$ hyaluronic acid or sodium hyaluronate 95\% (HA) (ACROS Organic, USA) supplemented with $5 \%$ bovine serum albumin (Vivantis Technology, Oceanside) and incubated for 24 to 48 hours at $37^{\circ} \mathrm{C}$. Then, the agar plate was treated with $2 \mathrm{~N}$ acetic acid for 10 minutes. The halo zone surrounding the colony was observed. Commercial hyaluronidase was used as positive control and culture broth without inoculum for negative control.

\section{Statistical Analysis}

The association analysis was carried using Pearson or Fisher Exact test through SPSS version 12.0 software. Any $p$-value $\leq$ 0.05 are deemed as significant value.

\section{RESULT AND DISCUSSION}

In total, 44 isolates were successfully detected from the 35 subjects. To find the association of hyaluronidase production with specific characteristics of the organism, all the isolates were further grouped based on colony surface morphology (mucoid and non-mucoid appearance), Gram staining and its shape. Majority of the isolates were non-mucoid $(n=34$, 77.3\%) while remaining 10 isolates $(22.7 \%)$ were mucoid colony. Half of the isolates $(n=22,50 \%)$ were Gram-positive and Gram-negative bacteria, and 34 isolates (77.3\%) were cocci while remaining 10 isolates $(22.7 \%)$ were rod in shape (Figure 1). 


\section{Bacterial characteristics, $n=44$}
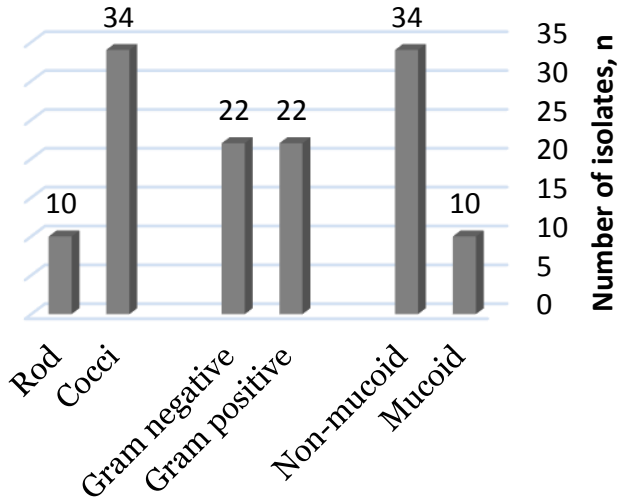

Figure 1. Distribution of Streptococcus pneumoniae isolates into bacteria shape, Gram's group and colony surface morphology

In the present study, the biofilm production was detected from 18 hours of incubated bacterial culture. In the previous study, biofilm formation was detected as early as 4 hours and reach maximum production after 8 hours incubation (Gutierrez et al. 2016). In this study, biofilm was detected in all isolates, which further classified as a weak, moderate and strong producer. In combination, $72.72 \%$ of the isolates are moderate and strong biofilm producer (Figure 2). The association analysis showed biofilm production has no significant association with any of bacterial characteristics (Table 1).

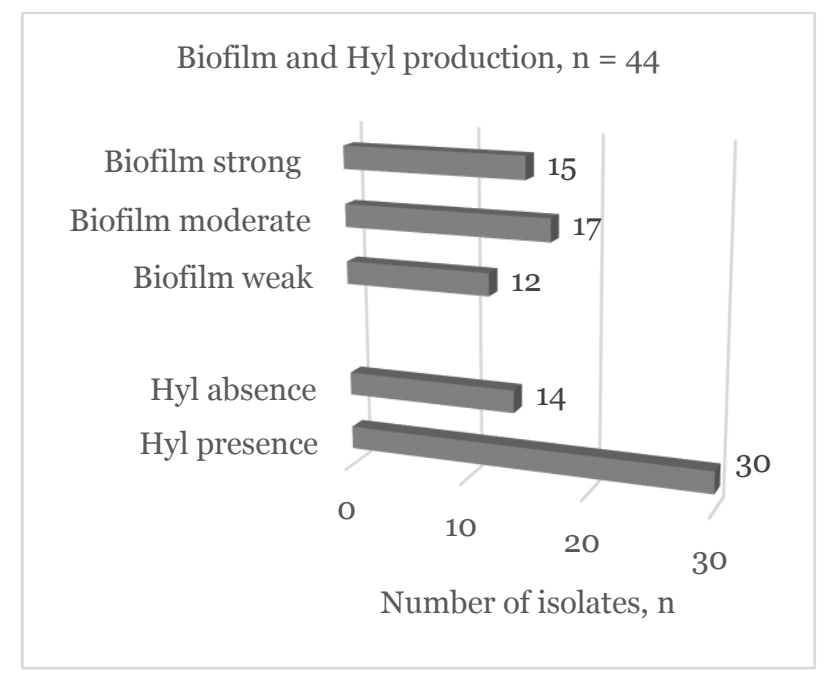

Figure 2. Biofilm and Hyl production in all isolates

While for Hyl production, the majority of the isolates were positive ( $\mathrm{n}=30,68.2 \%$ ) (Figure 2). All isolates with a mucoid appearance on the agar plate presence with Hyl production
(100\%), where a significant association between $\mathrm{Hyl}$ production and colony morphology $(p=0.018)$ was observed. Table 2 also shows a slight preponderance of Gram-negative bacteria to produce $\mathrm{Hyl}$, without evidence of significant association value. Another significant value was observed for rod-shaped bacteria to produce Hyl (100\%) $(p=0.018)$ (Table 2).

Further analysis showed a majority of moderate biofilm producer are Hyl producer (43.3\%). However, no significant association value was identified between these criteria (Table 3).

Table 1. Association of biofilm production and bacterial characteristics

\begin{tabular}{lllll}
\hline & \multicolumn{3}{c}{ Biofilm producer, n (\%) } & $\begin{array}{l}p \text { - } \\
\text { value }\end{array}$ \\
\cline { 2 - 4 } & Weak & Moderate & Strong & \\
\hline $\begin{array}{l}\text { Mucoid } \\
\begin{array}{l}\text { Non- } \\
\text { mucoid }\end{array}\end{array}$ & $\begin{array}{l}3(30.0) \\
9(26.5)\end{array}$ & $\begin{array}{l}3(30.0) \\
14(41.2)\end{array}$ & $\begin{array}{l}4(40.0) \\
11(32.4)\end{array}$ & 0.818 \\
\hline Gram & $7(31.8)$ & $8(36.8)$ & $7(31.8)$ & \\
$\begin{array}{l}\text { positive } \\
\text { Gram } \\
\text { negative }\end{array}$ & $5(22.7)$ & $9(40.9)$ & $8(36.4)$ & 0.863 \\
\hline $\begin{array}{lllll}\text { Cocci } \\
\text { Rod }\end{array}$ & $\begin{array}{l}\text { 3(30.0) } \\
9(26.5)\end{array}$ & $\begin{array}{l}3(30.0) \\
14(41.2)\end{array}$ & $\begin{array}{l}4(40.0) \\
11(32.4)\end{array}$ & 0.818 \\
\hline
\end{tabular}

Table 2. Association of Hyl production and bacterial characteristics

\begin{tabular}{llll}
\hline & \multicolumn{2}{l}{ Hyl production, $\mathrm{n}(\%)$} & \multirow{2}{*}{ p-value } \\
\cline { 2 - 3 } & Presence & Absence & \\
\hline Mucoid & 10 (100.0) & O (0.00) & \multirow{2}{*}{ o.o18* } \\
Non-mucoid & $20(58.8)$ & $14(41.2)$ & \\
\hline & & & \\
Gram positive & $13(59.1)$ & $9(40.9)$ & \multirow{2}{*}{0.332} \\
Gram negative & $17(77.3)$ & $5(22.7)$ & \\
\hline & & & \\
Cocci & $20(58.8)$ & $14(41.2)$ & \multirow{2}{*}{$\mathbf{0 . 0 1 8 *}$} \\
Rod & $10(100.0)$ & $0(0.0)$ & \\
*significant at $p \leq 0.05$ & &
\end{tabular}

Table 3. Association between biofilm and Hyl production

\begin{tabular}{lllll}
\hline & \multicolumn{3}{c}{ Biofilm producer, n (\%) } & $\begin{array}{l}p \text { - } \\
\text { value }\end{array}$ \\
\cline { 2 - 4 } & Weak & Moderate & Strong & \\
\hline $\begin{array}{l}\text { Hyl } \\
\text { presence }\end{array}$ & $8(26.7)$ & $13(43.3)$ & $9(30.0)$ & \\
$\begin{array}{l}\text { Hyl } \\
\text { absence }\end{array}$ & $4(28.6)$ & $4(28.6)$ & $6(42.9)$ & 0.659 \\
\hline
\end{tabular}

A study conducted by Pecharki et al. (2008) found that Hyl promotes detachment of biofilm and the results of $18 \mathrm{~h}$ of exposure HA-grown biofilms to Hyl strongly reduced the 
biofilm mass. In an earlier study, Yadav et al. (2013) observed increases in biofilm biomass when grown in medium supplemented with HA, and they demonstrated that the HA supports Streptococcus pneumoniae growth. However, no association of $\mathrm{Hyl}$ and biofilm production were investigated in their study. Ibberson et al. (2016), also reported that in an established HA-containing biofilm, the induction of $\mathrm{Hyl}$ resulted in biofilm dispersal compared to uninduced control and confirmed their findings that exogenous Hyl could detach HA-containing biofilm. The detachment of biofilm by Hyl enzyme is achieved through degradation of the HA substrates, which was supplemented in the biofilm growth media (Kaplan 2010).

Association between biofilm and Hyl activity was investigated in limited studies, among specific bacterial species. This valuable information could explain the pathogenesis of the bacteria, but a confirmation is needed for other bacterial species, especially in common biofilm producer in human. In human, biofilm is highly produced in the oral cavity. Therefore this study is specifically aimed to investigate the association of biofilm and $\mathrm{Hyl}$ activity in bacteria isolated from the oral cavity of a healthy individual. In addition, the study was also looking for any association of biofilm and Hyl with bacterial characteristics including their Gram's staining group, colony morphology and bacterial shape.

In the previous study, Hyl in Streptococcus intermedius, a common bacteria causing abscess formation (Whiley et al. 1992; Tran et al. 2008) was found to correlate with biofilm activity by dispersing the biofilm and facilitate new biofilm formation at a different site (Pecharki et al. 2008). In another study, the elevated amount of Hyl was detected in the mutant strain of Staphylococcus aureus lacking biofilm, but no significant correlation was declared (Hart et al. 2013). Most of the studies, albeit low in number, reports on Gram-positive bacteria, while information available for Gram-negative bacteria is lacking.

The present study found that Hyl production is not associated with biofilm production. Combination of biofilm and Hyl production level (e.g. Strong biofilm producer and Hyl producer) also not significantly associated with the aforementioned bacterial characteristics (data not shown). From this association analysis, this finding indicates a lack of contribution of Hyl in biofilm activity. However, further study should be done by looking at the involvement of $\mathrm{Hyl}$ production during biofilm formation (in situ), which may give a better understanding of the association between these two components.

Based on Table 1, almost equal distribution of biofilm level (weak, moderate, strong) found among Gram-positive isolates. However, a slight preponderance Gram-negative isolates to produce moderate and strong biofilm. Lee et al., (2016) showed that the biofilm formation of Gram-positive bacteria is influenced by lipoteichoic acid available on cell wall meanwhile Gram-negative biofilm formation is influenced by lipopolysaccharide (LPS) found in the outer membrane. However, Table 1 showed no association was found between biofilm formation and Gram bacteria group which is similar to Mai-Prochnow et al. (2016) who observed similar biofilm biomass in Gram-positive and Gram-negative bacterial isolates and suggested that other factors are responsible for biofilm thickness and structure. In bacteria, Gram staining classification is based on the cell properties correlated with the cell wall. Although the differences of biofilm in both class not widely discussed, the thickness and structure of both classes are found similar (Mai-Prochnow et al. 2016). Differences of cell wall properties in Gram-positive and Gram-negative bacteria may affect the bacterial attachment to the surface, the first stage in biofilm formation (Renner \& Weibel 2011). The other factors that may influence the formation of biofilm are the composition of the surrounding environment that may affect the bacterial attachment to the surface (Renner \& Weibel 2011; Fysun et al. 2019). Marks et al. (2012) demonstrating higher biofilm formation in Streptococcus pneumoniae strain which lack of capsules. In that study, they found that lacking the capsules increase the bacterial binding to the host cells, which later increase the colonization, likewise the biofilm formation.

Similar findings were observed in other studies where the production of capsules block the formation of biofilm in Prophyromonas gingivalis, Vibrio vulnificus and Neiserria meningitidis (Joseph et al. 2004; Yi et al. 2004; Davey et al. 2006). Firm attachment of bacteria to host cells is a critical stage for biofilm development. Attachment of bacteria to the biotic or abiotic surface relies on many factors, including surface proteins which act as adhesin or adherence factors. 
Attenuated glycosyltransferase in Porphyromonas gingivalis produced immature fimbriae which affect the ability of the bacteria to perform autoaggregation and gave a severe impact on its adherence capability (Narimatsu et al. 2004). In addition, surface protein gingipains play the main role in $P$. gingivalis adherence to other bacterial or human epithelial cells (Tokuda et al. 1996). Covering the surface protein by the capsule (Mesnage et al. 1998) might reduce the adherence capacity of the surface protein, further affect the biofilm formation. In the present study, no significant association was recorded between biofilm formation and mucoid and non-mucoid isolates. This finding needs further investigation, by considering other factors to be included, such as the species of the bacteria.

In term of Hyl production, a significant association was identified for colony morphology and bacterial shape, while no significant association for Gram's classification group. Although no significant differences were identified between Gram-positive and Gram-negative bacteria, it interesting to observe more than $77 \%$ of Gram-negative isolates possess $\mathrm{Hyl}$ activity (Table 2). In previous studies, various Hyl producer was reported among Gram-positive bacteria including Streptococcus pneumoniae, Streptococcus agalactiae, Streptococcus Group A and B and Streptomyces spp. (Ohta \& Kaneko 1970; Calvinho et al. 1998; Sellin et al. 1998; Starr \& Engleberg 2006; Yusof et al. 2015), while few reported on Gram-negative bacteria, including Propionibacterium acnes (Tyner \& Patel 2015). Therefore, the authors are planning to identify the bacterial species further to add on more data on Hyl producer in Gram-negative bacteria. In Gram-negative bacteria, the production of enzyme is in periplasmic space, the zone between the cytoplasmic membrane and outer membrane that contain abundant proteins (Hynes \& Walton 2000).

Meanwhile, in Gram-positive bacteria, this enzyme is retained in or near the cell membrane instead (Silhavy et al. 2010). Thus, the difference in locations of proteins responsible for $\mathrm{Hyl}$ secretion between Gram-positive and Gram-negative might influence the difference in Hyl activity. This assumption needs further analysis to confirm the differences.

Hyaluronidase production was found to associate with the mucoid appearance colonies on the agar plate. This is similar to Yusof et al. (2015) who also found high Hyl producer in mucoid colonies of Streptococcus pneumoniae. Mucoid colonies which appear like a water-glistening and most of the time become confluent on the agar plate are related to the production of slime and capsule by the cell (Kandi 2015). Capsulated bacteria represent more capsular materials and usually indicate higher virulence of the bacteria since the capsule could prevent the phagocytosis by host immune system (Kelly et al. 1994). One of the possible explanations is for high $\mathrm{Hyl}$ in capsulated bacteria is to degrade the capsule, thus enhance the bacterial adherence to the host tissues. This explanation is highly applicable for Streptococcus pyogenes, where the capsule are highly made of hyaluronic acids, the substrate for Hyl (Starr \& Engleberg 2006). However, the significance of high capsulated materials and Hyl activity in bacteria producing non-HA capsules such as $S$. pneumoniae and other bacteria are currently unknown.

Another significant association found is all the rod shape bacteria producing Hyl. This finding contradicts to the previous study, which rarely found hyaluronidase producer among rod-shaped bacteria, except in Bacillus sp., Clostridium perfringens and Propionibacterium acnes (Hynes \& Walton 2000; Guo et al. 2014). Since the present study does not identify the isolates up to species level, it is unclear if all the rod shape isolates represent one or more bacterial species. Thus further analysis is needed to confirm the association.

\section{CONCLUSION}

In the current study, the data showed all oral cavity isolates produce biofilm in various amount, and the majority of them are Hyl producer. Although this number could not explain the exact role and mechanism of $\mathrm{Hyl}$ in bacterial pathogenesis, it may indicate the capability of the certain bacterial group to produce these two virulence factors. There is no significant association between biofilm and Hyl production, however, in situ tests for Hyl production during biofilm formation or at other stages is needed for better understanding. A significant association was found for mucoid colony and rod shape isolates which require further investigation to understand the relationship and its mechanism. 


\section{ACKNOWLEDGEMENT}

This study was supported by research Initiative Grant

Scheme (RIGS) (RIGS 15-018-0018).

\section{REFERENCES}

Armstrong, SE \& Bell, DR 2002, 'Ischemia-reperfusion does not cause significant hyaluronan depolymerization in skeletal muscle', Microvascular Research, vol. 64, pp. 353362.

Calvinho, LF, Almeida, RA \& Oliver, SP 1998, 'Potential virulence factors of Streptococcus dysgalactiae associated with bovine mastitis', Veterinary Microbiology, vol. 61, no. 1-2, pp. 93-110.

Christensen, GD, Simpson, WA, Younger, JJ, Larry, M, Barrett, FF, Melton, DM \& Beachey, EH 1985, 'Adherence of coagulase-negative staphylococci to plastic tissue culture plates: a quantitative model for the adherence of staphylococci to medical devices', Journal of Clinical Microbiology, vol. 22, no.6, pp. 996-1006.

Dahiya, P \& Kamal, R 2013, 'Hyaluronic acid: a boon in periodonta therapy', North American Journal of Medical Sciences, vol. 5, no. 5, pp. 309-315.

Davey, ME \& Duncan MJ 2006, 'Enhanced biofilm formation and loss of capsule synthesis: deletion of a putative glycosyltransferase in Porphyromonas gingivalis', Journal of Bacteriology, vol. 188, no. 15, pp. 5510-5523.

Fitzgerld, TJ \& Gannon, EM 1983, 'Further evidence for hyaluronidase activity of Treponema pallidum', Canadian Journal of Microbiology, vol. 29, pp. 1507-1513.

Fysun, O, Kern, H, Wilke, B \& Langowski, HC 2019, 'Evaluation of factors influencing dairy biofilm formation in filling hoses of food-processing equipment', Food and Bioproducts Processing, vol. 113, pp. 39-48.

Guo, X, Shi, Y, Sheng \& J, Wang, F 2014, 'A novel hyaluronidase produced by Bacillus sp. A50', PLOS ONE, vol. $9, \quad$ no. 4, e94156, doi: .org/10.1371/journal.pone.0094156.

Gutierrez, D, Hidalgo-Cantabrana, C, Rodriguez, A, Garcia, P \& Ruas-Madiedo, P 2016, 'Monitoring in real time the formation and removal of biofilms from clinical related pathogens using an impedance-based technology', PLoS ONE, vol. 11, no. 10, pp. e0163966. doi: 10.1371/journal.pone.0163966.

Hart, ME, Hart, MJ \& Roop, AJ 2009, 'Genotypic and phenotypic assessment of hyaluronidase among type of strains of a select group of staphylococcal species', International Journal of Microbiology, vol. 2009, 614371. doi: 10.1155/2009/614371.

Hart, ME, Tsang, LH, Deck, J, Daily, ST, Jones, RC, Liu, H, Hu, H, Hart, MJ \& Smeltzer, MS 2013, 'Hyaluronidase expression and biofilm involvement in Staphylococcus aureus UAMS-1 and its sarA, agr and sarA agr regulatory mutants', Microbiology, vol. 159, no. Pt 4, pp. 782-791.

Hynes, WL \& Walton, SL 2000, 'Hyaluronidases of Grampositive bacteria', FEMS Microbiology Letters, vol. 183, no. 2, pp. 201-207.

Ibberson, CB, Jones, CL, Singh, S, Wise, MC, Hart, ME, Zurawski, DV \& Horswill, AR 2014, 'Staphylococcus aureus hyaluronidase is a CodY-regulated virulence factor', Infection and Immunity, vol.82, no. 10, pp. 4253-4264.

Ibberson, CB, Parlet, CP, Kwiecinski, J, Crosby, HA, Meyerholz, DK \& Horswill, AR 2016, 'Hyaluronan modulation impacts Staphylococcus aureus biofilm infection', Infection and Immunity, vol. 84, no. 6, pp. 19171929.

Joseph, LA \& Wright, AC 2004, 'Expression of Vibrio vulnificus capsular polysaccharide inhibits biofilm formation', Journal of Bacteriology, vol. 186, pp. 889-893. Juhlin, L 1997, 'Hyaluronan in skin', Journal of Internal Medicine, vol. 242, no. 1, pp. 61-66.

Kandi, V 2015, 'Bacterial capsule, colony morphology, functions, and its relation to virulence and diagnosis', Annals of Tropical Medicine and Public Health, vol. 8, pp. 151-153.

Kaplan, JB 2010, 'Biofilm dispersal: mechanisms, clinical implications, and potential therapeutic uses', Critical Reviews in Oral Biology \& Medicine, vol. 89, no. 3, pp. 205-218.

Kelly, T, Dillard, JP \& Yother, J 1994, 'Effect of genetic switching of capsule type on virulence of Streptococcus 
pneumoniae,' Infection and Immunity, vol. 62, pp. 18131819.

Lee, KJ, Lee, MA, Hwang, W, Park, H \& Lee, KH, 'Deacylated lipopolysaccharides inhibit biofilm formation by Gramnegative bacteria', Biofouling, vol. 32, no. 7, pp. 711-723.

Mai-Prochnow, A, Clauson, M, Hong, J \& Murphy, AB 2016, 'Gram positive and Gram negative bacteria differ in their sensitivity to cold plasma', Scientific Reports, vol. 6, pp. 38610. doi: 10.1038/srep38610.

Marks, LR, Reddinger, RM \& Hakansson AP 2012, 'High levels of genetic recombination during nasopharyngeal carriage and biofilm formation in Streptococcus pneumoniae', mBio, vol. 3, no. 5, pp. e00200-eoo212.

Mesnage, S, Tosi-Couture, E, Guonon, P, Mock M \& Fouet, A 1998, 'The capsule and S-layer: two independent and yet compatible macromolecular structures in Bacillus anthracis', Journal of Bacteriology, vol. 180, no. 1, pp. 5258.

Meyer, K \& Palmer, JW 1934, 'The polysaccharide of vitreous humor', Journal of Biological Chemistry, vol. 107, pp. 629634.

Narimatsu, M, Noiri, Y, Itoh, S, Noguchi N, Kawahara, T \& Ebisu, S 2004, 'Essential role for the gtfA gene encoding a putative glycosyltransferase in the adherence of Porphyromonas gingivalis,' Infection and Immunity, vol. 72, no. 5, pp. 2698-2702.

Necas, J, Bartosikova, L, Brauner, P \& Kolar, J 2008, 'Hyaluronic acid (hyaluronan): a review, Veterinarni Medicina, vol. 53, no. 8, pp. 397-411.

Ohya, T \& Kaneyo, Y 1970, 'Novel hyaluronidase from Streptomyces', Biochimica Et Biophysica Acta, vol. 198, no. 3, pp. 607-609.

Papakonstantinou, E, Kouri, FM, Karakiulakis, G, Klagas, I, Eickelberg, O 2008, 'Increased hyaluronic acid content in idiopathic pulmonary arterial hypertension', European Respiratory Journal, vol. 32, pp. 1504-1512.

Pecharki, D, Petersen, FC \& Scheie, AA 2008, 'Role of hyaluronidase in Streptococcus intermedius biofilm', Microbiology, vol. 154, no. 3, pp. 932-938.

Renner, LD \& Weibel, DB 2011, 'Physicochemical regulation of biofilm formation', MRS Bulletin, vol. 36, no. 5, pp. 347355 .

Sellin, M, Granlund, M, Linda, O \& Norgren, M 1998, 'Identification of a novel insertion element, IS 1548 , in Group B Streptococci, predominantly in strains causing endocarditis', Journal of Infectious Disease, vol. 177, pp. 967-976.
Silhavy, TJ, Kahne, D \& Walker, S 2010, 'The bacterial cell envelope', Cold Spring Harbor Perspectives in Biology, vol. 2, no. 5, pp. aooo414.

Smith, RF \& Willett, NP 1968, 'Rapid plate method for screening hyaluronidase and chondroitin sulfatase producing microorganisms', Applied Microbiology, vol. 16, no. 9, pp. 1434-1436.

Starr, CR \& Engleberg, NC 2006, 'Role of hyaluronidase in subcutaneous spread and growth of Group A Streptococcus, Infection and Immunity, vol. 74, no. 1, pp. 40-48.

Stepavonic, S, Vukovic, D, Dakic, I, Savic, B \& Svabic-vlahovic, M 2000, 'A modified microtiter-plate test for quantification of Staphylococcal biofilm formation, Journal of Microbiological Method, vol. 40, no. 2, pp. 175-179.

Tokuda, M, Duncan, M, Cho, MI \& Kuramitsu, HK 1996, 'Role of Porphyromonas gingivalis proetase activity in colonization of oral surfaces', Infection and Immunity, vol. 64, no. 10, pp. 357-363.

Tran, MP, Caldwell-McMillan, M, Khalife, W \& Young, VB 2008, 'Streptococcus intermedius causing infective endocarditis and abscesses: a report of three cases and review of the literature', BMC Infectious Diseases, vol. 8, no. 154. doi: 10.1186/1471-2334-8-154.

Tyner, H \& Patel, R 2015, 'Hyaluronidase in clinical isolates of Propionibacterium acnes', International Journal of Bacteriology, vol. 2015, ID 218918. doi: org/10.1155/2015/218918.

Whiley, RA, Beighton, D, Winstanley, TG, Fraser, HY \& Hardie, JM 1992, 'Streptococcus intermedius, Streptococcus constellatus, and Streptococcus anginosus (the Streptococcus milleri group): association with different body sites and clinical infections', Journal of Clinical Microbiology, vol. 30, no. 1, pp. 243-244.

Yadav, MK, Chae, SW, Park, K \& Song, JJ 2013, 'Hyaluronic acid derived from other Streptococci supports Streptococcus pneumoniae in vitro biofilm formation', BioMed Research International, vol. 2013, 690217. doi: 10.1155/2013/690217.

Yi, KA, Rasmussen, AW, Gudlavalletu, SK, Stephens, DS \& Stojiljkovic, I 2004, 'Biofilm formation by Neisseria meningitidis', Infection and Immunity, vol. 72, pp. 61326138.

Yusof, AY, Des, MNM, Masri, SN, Malina, O \& Jamal, F 2015, 'Hyaluronatelyase production by Streptococcus pneumoniae isolated from patients and carriers', Tropical Biomedicine, vol. 32, no.3, pp. 413-418. 